\title{
ІННОВАЦІЙНА ЛЕКСИКА В ДОБУ ПОЛІТИЧНИХ ТРАНСФОРМАЦІЙ: ЗБАГАЧЕННЯ ЧИ ВТРАТА ІДЕНТИЧНОСТІ
}

\author{
Черемська О. С., Сухенко В. Г.
}

\section{ВСТУП}

Мова, яка специфічно відтворює навколишній світ, постійно зазнає внутрішніх структурних змін. Соціальні чинники, історичні події та діяльність окремих особистостей стимулюють і спрямовують безпосередньо чи опосередковано - вектори мовного розвитку. Період соціально-політичних трансформацій зазвичай стає часом прискорення мовної динаміки. Активно зростає кількість інновацій, що впливає на співвідношення нормативних і ненормативних мовних явищ. Слово як основна одиниця мови стає поштовхом до суттєвих змін на різних рівнях мовної системи, оскільки соціальні чинники відразу знаходять своє відображення в суспільно-політичній лексиці.

Серед мовних явищ і процесів, спричинених новими формами суспільних відносин, найбільш поширені: запозичення, словотворчі неологізми, явища деархаїзації та їх освоєння, стилістична транспозиція; семантичні зміни в лексичних групах. Однак чи не найважливіше місце належить неологізації. Наприкінці XX - на початку XXI століття в більшості мов засвідчено «неологічний бум» ${ }^{1}$. Неологізація виявляється в появі нових слів, словосполучень, нових значень, актуалізації та функціональній переоцінці лексичних одиниць, які віддавна існують у мові. Мовна ситуація, мовна політика в Україні після 2004 р. посутньо змінювалися. Помітних зрушень зазнала сама українська мова, зокрема іiї лексико-семантичний склад. У зв'язку із цим актуальною постає проблема збереження мовної ідентичності, тобто дотримання нормативності вислову на різних рівнях мовної системи.

У працях, присвячених екології української й інших мов, простежується думка про те, що сьогодні, в епоху глобалізації та руйнівних лінгвістичних агресій, мова потребує захисту (Б. Ажнюк, В. Акуленко, О. Бондар, Л. Бордюк, О. Земська, В. Іванов,

Стишов О. Динаміка лексичного складу сучасної української мови. Лексикологія. Лексикографія : навчальний посібник. Біла Церква : Авторитет, 2019. C. 30 . 
В. Костомаров, Л. Масенко, М. Мірченко, А. Нелюба, Є. Редько, О. Сербенська й інші). Такий захист може забезпечити лише суспільство, яке послуговується цією мовою. Активізація міжкультурної комунікації зумовлює потребу дослідження специфіки сприйняття й усвідомлення соціумом нових понять, визначення місця та ролі інноваційних лексичних засобів у системі знань про світ. Вплив інноваційних процесів на свідомість мовної особистості досконало не вивчений. Потребує вирішення проблема формування, національно-мовного сприйняття мовної картини світу під дією неологічних вербальних засобів.

Мета статті - дослідити й узагальнити найважливіші інноваційні зміни в лексиці сучасної української мови, спричинені впливом екстралінгвальних чинників - політичними подіями сучасної доби.

Наукова новизна полягає в дослідженні екологічного аспекту функціонування української мови на ілюстративному матеріалі, що відображає процеси адаптації інноваційної лексики початку XXI століття, яка об'єктивує суспільно-політичні трансформації в Україні сучасного періоду.

\section{1. Вплив неологізмів доби на мовну особистість}

Термінологічна система неології має низку позначень і дефініцій: новотвір, неотвір, новачія, інновація, нова номінація, неономінація, нове найменування, нововведення, неологізм, неонім, неоверб, неонейм

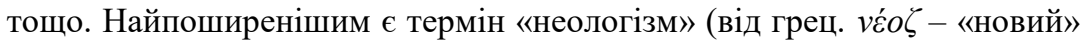

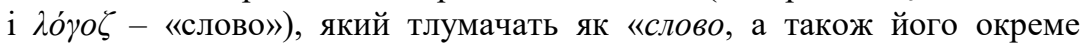
значення, вислів, які з'явилися в мові на даному етапі ії розвитку (загальномовні неологізми) або були вжиті тільки в певному акті мовлення, тексті чи мові конкретного автора (стилістичні, або індивідуально-авторські, неологізми; пор. оказіоналізм)» ${ }^{2}$. Однак із часом цей термін розширив своє значення, він уже не може задовольняти основної вимоги, яку висувають до спеціального найменування, - однозначність. У періоди соціальних перетворень, коли «неологізми на годину» - слово або вираз - з'являються разом із явищем, функціонують у мовленні впродовж короткого терміну, а згодом зникають, не потрапивши до словників. Час змінює усталені уявлення, зокрема і про класичну схему суспільство - мовлення -

2 Тараненко О. Неологізм. Українська мова : енциклопедія. Київ : Укр. енциклопедія ім. М. Бажана, 2004. С. 408. 
мова - суспільство (неологізм - адаптація - норма), і про можливість особистості впливати на мовну норму тощо ${ }^{3}$.

Поняття «інновація», «новотвір», «нововведення» тлумачать як абсолютні синоніми. Терміни «неологізм» і «новотвір» мають низку відмінних ознак: новотвори виникають у мові як першочергові та єдині назви нових понять, а неологізми з'являються як синоніми, що містять додаткову інформацію ${ }^{4}$.

У зв'язку з неологізацією постає проблема впливу цього процесу на мову та мовну особистість і необхідність його скеровування, на що звертав увагу О. Потебня. Обгрунтовуючи психологічну модель творення слова, як згадує потебнянець О. Ветухов, учений наголошував на необхідності свідомого впливу суспільства на мовців: «Прогресивність і консерватизм це вдих і видих людської думки. Пуризм настільки ж важливий і потрібний в еволюції мови, як і відчайдушна творчість, але ні те, ні інше не створює величі мови, ні їі розквіту <..> Мова перелому, мова переходу від одних культурно-побутових форм до інших, звичайно святотатственно порушує правила граматики і стилістики, - це його стихія <..> Показником культури є не ці новинки - їх скрізь досить, але ставлення до них верхів грамотність цих верхів. Не можна загородити потік, але можна спрямувати його. Не можна викоренити ні вульгарне тяжіння до нових словечок, ні озлоблену ненависть до нового слова, але можна навчити людей розумно і дбайливо ставитися до своєї мови» ${ }^{5}$ (виділення наше - O. Ч.; В. C.).

Мовній особистості властива мовна свідомість, яка фіксує та впорядковує знання людини про світ. Слово як засіб апперцепції, за О. Потебнею, є насамперед засобом розуміти мовця, апперципіювати зміст його думок 6 . Йому властива креативна функція: слово збуджує пізнавальні механізми свідомості й таким чином «мова об'єктивує думку» ${ }^{7}$. Вивчення ментального складника мовної свідомості, розвинуте в українському мовознавстві О. Потебнею, відкриває перспективу для нових наукових розвідок. Ментальний простір як система уявлень про світ постає в лінгвістичних дослідженнях сьогодення (С. Бибик, Т. Власевич, I. Грабовська, С. Срмоленко, Н. Непийвода, П. Селігей, Л. Струганець, В. Храмова й інші). Менталітет як складник мовної особистості відображає особливість

${ }^{3}$ Семенюк О. Особливості сучасної комунікації як фактори впливу на процеси функціонування і засвоєння неологізмів. Наукові записки. Серія «Філологічні науки». Кіровоград, 2016. Вип. 145. С. 3.

${ }^{4}$ Косович О. До питання про суть неологізму в сучасній лінгвістиці. Записки з романо-германської філології. 2012. Вип. 2. С. 72.

${ }^{5}$ Ветухов А. Потебнианство. Родной язык в школе. 1923. Кн. 1. С. 115-116.

${ }^{6}$ Потебня А. Слово и миф. Москва : Правда, 1989. С. 123.

${ }^{7}$ Там само. С. 237. 
сприйняття світу певною групою людей, об'єднаною спільною мовою, територією, національністю тощо. Фактично ментальність народу $\epsilon$ проявом його характеру, реалізованого в діях та комунікативній поведінці.

Сьогодні демократизація цінностей переформовує політичний устрій, релігійні орієнтації, гендерні ролі, соціальні норми, розширює життєвий простір, прискорює та спрощує процес передавання інформації, міжособистісної та міжетнічної комунікації. Як відомо, кожний історичний період має свої словесні маркери, які виконують функцію позначення соціально-актуальних явищ, реалій, посідають важливе місце в дискурсі відповідної епохи, активно вживаються в засобах масової інформації, є невід'ємним складником мови політики, пропаганди й побутового спілкування. Початок XXI ст. (а саме період від 2004 р. і дотепер) ознаменований зміною політичного вектора і євроінтеграцією відповідно: від Помаранчевої революції (листопад грудень 2004 р.) та протестних акцій самого Майдану (Свромайдан), що почалися у грудні 2013 р., безперервно тривали протягом року і призвели власне до самої Революції Гідності. За короткий історичний час в Україні відбулися події, зміст яких становить підгрунтя якісно нової суспільної організації, державності й людських стосунків. 3 огляду на зазначене, дослідження лексики періоду громадянського суспільства нового типу вимагає встановлення й аналізу лінгвістичного зв'язку подій із соціокультурним розвитком країни. Адже державотворчу функцію мови можна порівняти із значенням державної символіки: як символіка національної держави (прапор, герб, гімн) виокремлює це суспільне утворення серед інших національних держав, так і державна мова репрезентує особовість, цілісність держави ${ }^{8}$.

Так, Революція Гідності дістала назву Євромайдан (масові багатотисячні акції в Україні на підтримку європейського вектора політики держави). Сьогодні Україну не уявити без такого символу, як Майдан. Він відображає важливу віху в українській історії становлення української політичної нації, а також уособлює символ самодостатнього, гордого, вільного народу, який вірить у своє майбутне й сам невпинно наближає його ${ }^{9}$. Слово-поняття Майдан спричинило словотворчий процес: Антимайдан (короткотривалий мітинг, підкріплений адміністративним ресурсом, на підтримку чинної влади і проти євроінтеграційного курсу України), Автомайдан (Майдан

${ }^{8}$ Єрмоленко С. Мова і українознавчий світогляд : монографія. Київ : НДІУ, 2007. C. 82.

9 Степаненко М. Політичне сьогодення української мови: актуальний перифрастикон : монографія. Харків, 2017. С. 10-11. 
на колесах, що складався 3 колони автомобілістів, які чинили опір владі), Веломайдан (мітинг на велосипедах харківських активістів, які проїхали вулицями міста на підтримку Євромайдану). Від лексеми Майдан у новому іiі семантичному форматі утворилася низка похідних слів із позитивно або негативно конотованим змістом: майданер, майданівець, майданізм, майдаун, майданити, майданник, майданство, майданс, майданофоб, майданикувати тощо. Засвідчено, що іменник Майдан уже поповнив словники мов різних континентів ${ }^{10}$.

Опозиційну силу, сформовану у 2013 р., називають тітушки - це збірний образ проплачених «гопників», молодих людей спортивної статури, що застосовували силу для протидії демократичним діям Євромайдану й зазнали поразки (термін в Україні з'явився у травні 2013 р. й походить від прізвища спортсмена Вадима Тітушка). Перехід власних імен у загальні, пов'язаний зі зміною сутності денотата, активізує словотворчі процеси: «Породжене несприятливою суспільнополітичною ситуацію слово «тітушки», ставши назвою нового явища, ввійшло до сучасного лексикону і як лексична одиниця асимілювалося в мові на рівні дериваційних процесів. Приклад: «Гепотітушки»»» ${ }^{11}$.

Як наслідок, почався активний процес деколонізації, а саме декомунізації, названий ленінопад, вождепад через характерну рису повалення монументів вождя. 3'являється саркастичне розмовне поняття совок, що характеризує мислення пересічного мовця крізь незмінну призму міфів СРСР та $є$ трансформованим від наукового Homo Sovieticus (псевдолат.) - назви критично-сатиричного твору Олександра Зинов'єва.

Після 2014 р. поширення набуло слово ватник, яке з'явилося у 2011 р. в мемі (смішна інтернет-картинка) і вважається похідним від назви теплого одягу, куфайки - «ватника», означає збірний образ людини антизахідного, антиукраїнського, проросійського, (пост)радянського менталітету. На противагу «ватнику» виникла лексема вишиватник - (вишиванка + ватник), що позначає малоосвіченого українського патріота, який не здатний аналізувати суспільно-політичні процеси, агресивно налаштований до всього російського, а його патріотизм зводиться тільки до носіння вишиванки. Однак можна припустити, що використання цієї лексеми має значно глибше підгрунтя. В основу образу покладено національний символ -

10 Степаненко М. Політичне сьогодення української мови: актуальний перифрастикон : монографія. Харків, 2017. С. 15.

11 Євграфова А. До питання про конотативні можливості власного імені (за матеріалами медіа). Сучасна україністика : наукові парадигми мови, історії, філософії : матеріали IV Міжнародної наукової конференції : збірник статей. Харків, 2014. С. 94. 
вишиванку. Поєднання із завідомо негативним поняттям «ватник» спричинює стирання ціннісних для кожного українця характеристик. У результаті суспільству нав'язують негативний ярлик-насмішку, який «чіпляють» кожному, хто використовує національну символіку ${ }^{12}$.

Підтримка України європейським суспільством через анексію Криму Росією 2014 р. спричинила появу таких лексичних новоутворень, як «Кримнаш» - найвідоміший російськомовний неологізм, що виник та набув популярності в Росії на тлі підготовки та здійснення російської збройної агресії проти України та під час анексії Криму. Згодом неологізм поширився і в Україні як глузливий інтернет-мем, іноді - разом зі своїм глузливим дзеркальним відбиттям «Намкриш» ${ }^{13}$; скримити, скримздити, що означає незаконно відхопити, КРИМіналітет (Крим + криміналітет), Кримль (Крим + Кремль) уживається у значенні «півострів Крим, окупований Росією». Неологізація в політичному дискурсі насамперед пов'язана із процесами появи нових слів та розвитком нових мовних явищ у політичному мовленні ${ }^{14}$.

Військові дії на Сході України ознаменували появу таких понять, як: кіборг (скорочення від біологічного наукового терміна «кібернетичний організм», що у фантастиці позначає напівлюдинунапівмашину; почало активно вживатися після 2014 р. на позначення воїна - учасника боїв за Донецький аеропорт, семантично пов'язано зі стійкістю, нездоланністю українських захисників); добробути (скорочення від «добровольчі батальйони», які були сформовані для ведення бойових дій на Донбасі); укроп (уперше 3 негативним значенням застосований Стрєлковим-Гіркіним як шифр-код під час радіопереговорів із представниками терористичних Донецької народної республіки (далі - ДНР) та Луганської народної республіки (далі ЛНР) (воєнізовані сепаратистські угруповання, що діють на частині території Донецької та Луганської областей відповідно завдяки збройній допомозі Російської Федерації і претендують на визнання підконтрольної території як держави); згодом - 1. Партія від 2015 р.

12 Кирилюк О. Суспільно-політичні неологізми як віддзеркалення мовної картини воєнного протистояння. Наукові записки Національного університету «Києво-Могилянська академія». Серія «Мовознавство». 2018. Т. 1. С. 61.

${ }^{13}$ Коробка Г. Гумористичний інтрадискурс мовної картини світу окупованого Криму. Вісник Київського начіонального лінгвістичного університету. Серія «Філологія». 2018. Т. 21. № 1. С. 73.

${ }^{14}$ Кондратенко Н. Неологізми в сучасному українському політичному дискурсі : семантико-словотвірний аспект. Наукові праці Кам'янець-Подільського національного університету імені Івана Огієнка. Серія «Філологічні науки». 2014. Вип. 37. С. 152. 
«Українське об’єднання патріотів»; 2. Альбом гурту «Гайдамаки» 2015 р., що є скороченням від УКРаїнський ОПір).

Унаслідок укладання у 2017 р. у Брюсселі угоди про безвізовий режим для України з'явився неологізм безвіз, який став словом 2017 р., за версією словника «Мислово». Ця подія спричинила й утворення слова євробляхи на позначення явища нерозмитнення авто на європейських номерах.

Лексичні новоутворення номінують явища, які стосуються і внутрішньополітичних процесів: бандократія (банда + бюрократія) та кнопкодави (давити + кнопки; пов'язане із процедурою голосування за законопроєкти у Верховній Раді), якими характеризують українських політиків та їхню діяльність; прихильників відповідної політичної сили: порохоботи, зелеботи, рашисти, колоради; конкретних діячів: Допа - М. Добкін, Гепа - Г. Кернес, Циклоп - Н. Шуфрич, Виломен О. Ляшко, Моніка Зеленські - В. Зеленський. А мітинги 2017 р., проведені М. Саакашвілі, позначають як Міхомайдан. Існування таких оцінних значень виконує емотивну функцію, вказує на погляди сучасників і асоціативні зв'язки.

Продуктивний тип номінувань становлять новотвори відонімного походження на позначення очільників, представників різних політичних сил, об'єднань, державних, громадських, військових інституцій: аваківець (від прізвища міністра внутрішніх справ України А. Авакова), кернодобкінець (за прізвищами міського голови Харкова Г. Кернеса й колишнього голови Харківської облдержадміністрації М. Добкіна), кличкіст (В. Кличко - Київський міський голова), порошенківиі (П. Порошенко - Президент України у 2014-2019рр.), фельдманівець (О. Фельдман - депутат Харківської міськради, народний депутат України), яценюківець (А. Яценюк - колишній Прем’єр-міністр України) тощо. Простежено, що в умовах війни, конфлікту більшість слів, які з'являються в мовленні, мають негативну конотацію, адже пов'язані з темою мови ненависті. Соціолінгвістичний аналіз (мовна здатність, жартівливість, стигматизація), як зазначає В. Іванов, допомагає виявити рівень політизації чи, навпаки, аполітизму ${ }^{15}$.

Лінгвісти припускають можливість появи значної кількості слівпаразитів, лінгвістичних покручів в академічних словниках. Сьогодні це слова й усталені вирази, добре відомі багатьом українцям, тому що нагадують про недавні політичні події: виборизми (вислови про вибори), портфелізація (збільшення владних посад), януагурація

15 Іваноў Уладзіслаў. Як мова рэагуе на расейска-ўкраінскую вайну (паліталягічныя і сацыялінгвістычныя заўвагі). The Ideology and Politics Journal. 2018. № 3 (11). C. 32-33. 
(інавгурація В. Януковича), гройсманоміка (економіка в Україні доби прем'єрства В. Гройсмана), противсіхство (явище, пов'язане 3 голосуванням проти всіх), депи (народні депутати), псевдовлада (несправжня влада), недотуркані (недоторканні народні депутати), корупець (той, хто пов'язаний із корупцією), олігархенята (дрібні олігархи). У політичній мові неореалій відчутний ідеологічний компонент їхньої семантики та спостерігається посилення тенденції до використання розмовних лексичних елементів як засобу оновлення образності. Уважаємо слушною думку мовознавців, які застерігають, що вводити неологізми такого типу до словникових видань передчасно.

\section{2. Відображення тенденцій епохи крізь призму неологізмів}

Важливою тенденцією доби, яка впливає на лексичний склад мови, $\epsilon$ глобалізація. Унаслідок iї дії значну кількість лексем запозичено 3 англійської мови шляхом транскрибування. Найпомітніше насичення ними засвідчене у професійній технічній лексиці, зокрема у сферах IT, політичній i адміністративній: вебократія (англ. webocracy) 1) онлайн-участь громадян у демократичних процесах, наприклад, онлайн-голосування під час виборів до парламенту; 2) спільна онлайнучасть користувачів у створенні вебконтенту; 3) марнування часу на пошук інформації в інтернеті (за аналогією з поняттям «бюрократія»); tендер (англ. gender - «стать») - соціальна стать, що визначає поведінку людини в суспільстві і те, як ця поведінка сприймається; краудсорсинг (англ. crowdsourcing; crowd - «натовп» + sourcing - «використання ресурсів») - спільна інтелектуальна робота в мережевому середовищі значної кількості незнайомих людей над спільним завданням; лобіст (англ. lobbyist від lobby) - особа, яка здійснює тиск на законодавців із метою ухвалення/відхилення тих чи тих законодавчих актів в інтересах певних осіб або їхніх груп; логроллінг (англ. logrolling «перекочування колоди») - процес взаємовигідного обміну підтримкою між політиками, зацікавленими в розв'язанні питань, що важливі для кожного; спічрайтер (англ. speech - «промова» + англ. write «писати») - різновид діяльності людини, яка займається підготовкою доповідей та промов для публічних людей, політиків, бізнесменів, представників шоу-бізнесу; трейдер (англ. trader) - учасник біржової торгівлі, який здійснює торгово-інвестиційні операції із цінними паперами, облігаціями, акціями й іншими фінансовими інструментами, 3 метою отримання прибутку. Отже, спостерігаємо взаємовплив мови та глобалізованого суспільства, наслідком якого $є$ перенасичення іншомовними елементами.

Як бачимо, мультикультурна комунікація призводить до часткової гібридизації української мови: відбувається уніфікація, стирання 
міжетнічних меж, що посилюється через інтернет і активну діяльність медіа. Лексична система мови зазнає відчутних змін через входження невиправданих запозичень, наприклад: інфотейнмент (англ. infotainment) - спосіб подачі інформації розважальними засобами; коворкінг (англ. co-working) - організація працівників в одному просторі; пейвол (англ. paywall) - сукупність технологій для організації платного доступу до матеріалу; сторітелінг (англ. storytelling) передача головних меседжів у скороченому вигляді; стрім (англ. stream) - спосіб відеопередачі інформації здебільшого розважального характеру у прямому ефірі; фактчекінг (англ. fact-checking) - перевірка достовірності джерел і фактів; фоловер (англ. follower) - дописувач.

Ці процеси потребують детального соціолінгвістичного та міжкультурного аналізу. Недоречні, поверхові вкраплення та спотворення англійських слів в українському дискурсі створюють комунікативний бар'єр. Спостерігається не взаємопроникнення і збагачення мов та культур, а порушення цілісності сприйняття світу. Негативного впливу зазнає не лише українська, але й англійська мова. Беззастережним $\epsilon$ той факт, що потрібно враховувати багатоаспектні наслідки глобалізації в різних сферах суспільного життя. Найбільш прийнятним рішенням могло б бути прагнення до розумної взаємодії та збалансованості моделей українського й західного дискурсів та уникнення їхнього антагонізму. Українську відкритість до світу варто врівноважити захистом рідної мови та послідовним, прагматично й естетично зумовленим вивченням чужих мов і культур ${ }^{16}$.

У зв'язку 3 розвитком технічної сфери відбувається часткове окнижнення лексичних одиниць, які з розряду слів-термінів переходять до загальновживаних: портал - великий сайт зі значним обсягом інформації, що об'єднує декілька тем, з огляду на інтереси великої аудиторії, забезпечує собі популярність; в’юер - програма для перегляду файлів певного формату; плагін - програмний модуль, що розширює функціональність основного застосунку; тіммейт - той, що грає в одній команді; бан - заборона, вигнання; браузер - програмне забезпечення для комп'ютера або іншого електронного пристрою; біткоїн - криптовалюта, електронна валюта; адаптер - пристрій для пристосування різних технологій. Значна частина слів інтернаціоналізми, що сприяє міжмовній комунікації. 3 огляду на

16 Бордюк Л. Екологія мови: український контекст. Україна - проблема ідентичності: людина, економіка, суспільство : Конференція українських випускників програм наукового стажування у США, Львів, 18-21 вересня 2003 р. Львів, 2003. С. 38. 
зазначене, англомовні запозичення в українському дискурсі доцільно класифікувати як прагматично обгрунтовані та необгрунтовані ${ }^{17}$.

Застосування новацій і технологій у сферах політики та бізнесу спричинило значні соціальні зміни (необхідність переходити на нові умови праці, пропонувати нові послуги, застосовувати інші підходи, уже відомі для країн із більш розвиненою економікою), що зумовили появу інноваційної лексики: гедж-фонд (англ. hedge fund) - приватний інвестиційний фонд із використання спільних коштів, який займається вкладенням капіталу, щоб максимально примножити кошти із чітко обумовленим або хитким ризиком; анбандлінг (англ. unbundling, від un + bundle) - добровільний поділ монолітних промислових груп на дрібніші самостійні структури; бріф (англ. brief) - невелика службова або доповідна записка 3 викладенням пропозицій, думок, ідей чи планів; нагадування, пам'ятка; офшорна зона (від англ. off shore) держава або іiі частина, яка на певних умовах надає особливий режим сприяння (реєстрації, діяльності, ліцензування, оподаткування тощо) компаніям-нерезидентам, зазвичай за умови ведення самої діяльності за межами окремої держави; роялті (англ. royalty, від фр. roialte) регулярна ліцензійна винагорода за використання патентів, авторських прав, природних ресурсів та інших видів власності; ф'ючерс (від англ. future) - терміновий біржовий контракт купівлі-продажу, за яким покупець і продавець узгоджують лише ціну й термін постачання.

Неологізація мови відображає перспективи України на міжнародній арені, демонструє те, що фахівці намагаються переймати досвід іноземних колег, розвиток окремих галузей науки та технологій, а отже, констатуємо активізацію інноваційних процесів словникового фонду, формування нового ідеолексикону, удосконалення засобів впливу на мовну особистість.

Серед інноваційних лексем, виокремлених у процесі аналізу, наявні явища інтерференції, спричиненої білінгвальністю соціуму. Зазвичай вони виконують комунікативне завдання, що полягає в мовній економії або необхідності надання особливого емоційного забарвлення висловлюваному: стрьомний - непривабливий, підозрілий, такий, що лякає; паліво - небезпека, те, що викликає підозру, хиба; реал/ріл реально; смомбі (нім. smombie: «смартфон» + «зомбі») - залежність від телефону; зомбоящик - телевізор; телепіпли - телеглядачі, які беззастережно вірять у надавану телебаченням інформацію; в язані (від

17 Бордюк Л. Екологія мови: український контекст. Україна - проблема ідентичності: людина, економіка, суспільство : Конференція українських випускників програм наукового стажування у США, Львів, 18-21 вересня 2003 р. Львів, 2003. С. 37. 
«в'язати спицями, гачком») - збірна назва місцевих жительок, переважно бабусь-пенсіонерок, які є прихильницями ДНР; дерибан процес розподілу матеріальних цінностей, здобутих незаконним шляхом; тушка - народний депутат, який відмовився підтримувати зв'язок у парламенті зі своєю політичною силою; тушкопад - масовий перехід депутатів з однієї фракції до іншої. Цей процес закономірний і пов'язаний безпосередньо із ситуативністю вживання таких слів та віковими особливостями мовців.

Ще одним наслідком впливу екстралінгвальних чинників є сленгізми: бімба (бомба), кіска (каска), папєрєднікі (попередники), кровосісі (кровососи), госпідар (господар) тощо - слова різновиду суржику азірівка, що названий за прізвищем чотирнадцятого Прем'єрміністра України М. Азарова (11 березня 2010 р. - 28 січня 2014 р.). Цей специфічний суржик популярний не тільки серед значної кількості політиків, а й у мережі Інтернет. В Україні запущений сервіс azirivka.blogspot.com, що дає змогу перекладати фрази й речення з української мови азірівкою. На жаль, більшість із цих одиниць мови укорінюються і з'являються у друкованих виданнях, як-от йолка чи Анна Ахмєтова (мовні помилки В. Януковича - Президента України 2010-2014 рр.).

Серед тенденцій сучасної мовної ситуації - прояви пуризації й актуалізації власне мовних одиниць: справочинецьь (замість діловод), відрядженець - той, хто перебуває у відрядженні (замість командировочний), вишівець (замість вузівець) тощо як наслідок «дистанціювання від країни-сусіда» ${ }^{18}$.

Посилення ролі інформації в суспільстві, зростання кількості працівників у сфері інформаційних/комп'ютерних технологій, існування глобального інфопростору - ознаки сучасного інформаційного суспільства. Ці чинники на тлі глобалізації й активного розвитку науки дають потужний поштовх мовній системі, яка має сприймати дефініції на позначення нових об’єктів. Україна посідає перші сходинки у світі за критеріями кількості та компетентності підготовлених фахівців IT-сфери і загальної кількості стартапів. Зважаючи на те, що міжнародна мова для айтішників (співробітники IT-сфери) - англійська, саме англізми здебільшого потрапляють до системи української через стратум мовного інтернет-простору. Значна кількість загальновживаних іншомовних запозичень зазнає семантичних замін: постити - оприлюднювати, лінкпосилання, редірект - перенаправлення, апдейт - оновлення, апгрейд покращення, юзер - користувач, патерн - шаблон, бал - хиба, фейл -

18 Степаненко М. Політичне сьогодення української мови: актуальний перифрастикон : монографія. Харків, 2017. С. 7. 
невдала спроба, поінт - мета. Такі слова називають «модними», тобто стилістично обмеженими, частково сленговими. Саме цей прошарок лексики найбільше переобтяжує мову запозиченнями, що завдячують моді в мові (термін О. Сербенської). Лінгвістична мода - це сукупність змінних уявлень про правильність і ефективність уживання мови, що панують у суспільстві в певний час; це змінний ідеал послуговування мовою, який відповідає характеру епохи, загальному мовленнєвому смаку.

Культивування модних тенденцій на сучасному етапі здійснюється в інтернет-просторі. Більшість запозичень потрапляють до лексикону українців саме через інноваційну уніфікацію, стирання етнічних, культурних, расових і лінгвістичних меж. У ракурсі поєднання процесів модернізації локальних культур із досягненнями глобальної мультикультурної цивілізації варто розглядати гібридизацію. Значна частина слів такого способу творення є сленговими: флудилка (англ. flood + укр. суфікс -илк-) - чат для значної кількості учасників, де багато повідомлень, що не мають інформаційної цінності; кава-брейк (англ. break) - перерва на каву; інвайтити (англ. invite + укр. суфікс -и+ укр. інфінітивне закінчення -ти) - запрошувати; спікати (англ. speak + укр. суфікс - $a$ - + укр. інфінітивне закінчення -mu) - розмовляти; постити (англ. post + укр. суфікс $-u$ - + укр. інфінітивне закінчення -ти) - публікувати допис у стрічці соціальної мережі; е-держава, e-вибори, е-голосування, е-парламент - електронна держава, електронні вибори, електронне голосування, електронний парламент.

Окремі неологізми з'являються в мові переважно 3 метою надання більшої емоційності найменуванням предметів чи осіб, які мали до цього стилістично нейтральну сему. Такі одиниці відображають тенденцію до активізації вживання експресивних форм, до необхідності вдосконалення мовного механізму, адже у вітчизняному політичному лексиконі сьогодні спостерігається значне неологічне піднесення, спричинене емоційністю, насиченістю, динамікою політичних процесів, ідеологічною поляризацією. Мова «розкріпачується» завдяки демократизації суспільно-політичного життя, зняття цензури та самоцензури, зростання особистісного начала. Під дією суспільнополітичних чинників у мові формується експресивний ідеолексикон, комплекс посилено-виразних слів, які мають соціальне звучання, містять соціальні конотації та здатні виражати соціальну оцінку дійсності. Це створює й можливості для маніпулювання суспільною свідомістю, дезінформації громадськості ${ }^{19}$.

19 Новітня політична лексика (неологізми, оказіоналізми та інші новотвори) / за заг. ред. Н. Хоми. Львів : Новий Світ - 2000, 2015. С. 3. 
Для розуміння специфіки сприймання мови, зокрема інноваційної лексики, наука оперує поняттями «менталітет», «мовна свідомість», «мовна картина світу». Менталітет та мовна картина світу перебувають у тісному взаємозв'язку: усі зміни в мовній картині світу детермінують зміни в ментальності та навпаки.

\section{ВИСНОВКИ}

У період бурхливих політичних подій в Україні XXI століття, зокрема Помаранчевої революції, Свромайдану, Революції Гідності, передумовами яких був той соціально-економічний стан, що формував психологічні настрої суспільства, виникли явища позамовної дійсності, які потребували лексичного вираження в українській мові.

За походженням новітня політична лексика створена двома шляхами: по-перше, це іншомовні запозичення, по-друге, утворення нових слів на основі питомої української лексики. Глобалізація продовжує сприяти активному проникненню до мовної системи англізмів. Однак варто зауважити, що у процесі адаптації цих слів роль російської як мови-посередника не виявлена.

Активний процес сучасності - неологізація, що, з одного боку, впливає на розвиток українського суспільства, 3 іншого, засвідчує неконтрольованість цього процесу. Значне збільшення неунормованих слів загрожує естетичній і культурологічній функціям мови.

Для лексичної системи мови досліджуваного періоду характерні такі процеси: 1) виникнення емоційно забарвлених одиниць на питомому грунті; 2) комбінаторика семантики, тобто зміна значення слова під дією певних чинників у момент переходу до мови-реципієнта (зазвичай можемо відстежувати асоціативний або логічний зв'язок між первинним i набутим значеннями слів); 3) орозмовлення та вульгаризація політичного дискурсу, що виявляються в появі стилістично зниженої та нелітературної, зокрема обсценної, лексики в політичній комунікації, навіть у мовленні політичних діячів і лідерів України. Це нівелює естетичну функцію мови та фактично сприяє викоріненню тенденції транслювання високих моральних принципів, справедливих життєвих засад тощо.

Усе зазначене дає підстави стверджувати, що у країні необхідно проводити ефективну просвітницьку кампанію серед політичних діячів, які $є$ публічними особами, з метою набуття ними вмінь дотримуватися мовних норм.

У текстовому викладі словникових видань $є$ потреба розмежовувати власне наукові політологічні терміни (кількість їх дедалі зростає) та сленгові новотвори громадсько-політичної сфери, які можуть бути презентовані для збереження для нащадків колориту епохи. 
Інноваційна лексика, поява якої зумовлена суспільно-політичними чинниками: рівнем розвитку й ідеологічним вектором національнодержавницької свідомості, стратегіями висвітлення подій у засобах масової інформації, світоглядними вподобаннями громадян, $\epsilon$ показником еволюції суспільно-політичної думки, індикатором вимірювання позитивних чи негативних настроїв суспільства.

Під час дослідження непростої мовної ситуації в Україні та складних лінгвальних явищ, характерних для мовного середовища держави доби політичних трансформацій, українські мовознавці зосереджують увагу на соціолінгвістичному підгрунті стану мови й актуалізують питання впливу на неї економічного та політичного чинників.

Отже, у сучасний період варто враховувати, що мова - гнучка система знаків, яка відповідає на всі сучасні виклики, що перед нею ставлять суспільство й час, та виконує свої функції. Водночас саме слова як мислетвірні пазли створюють відповідне уявлення про світ і хронологічний відрізок нашої чи будь-якої іншої доби, відповідають за можливості комунікувати, взаємодіяти та самовдосконалюватися відповідно до потреб.

Особливо треба подбати про збереження традиції світосприйняття й мовомислення, закодованих у слові, через здійснення екологічної мовної політики в державі. Варто докладати зусиль, щоб українська мова XXI століття не наблизилася до субстрату вулиці, натовпу, інтернет-мови, щоб не зруйнувався культурний шар витвореної впродовж століть української літературної мови, узвичаєної в сучасних засобах комунікації й управління, із розвиненою термінологією в усіх сферах суспільного буття.

\section{АНОТАЦІЯ}

У статті здійснено аналіз інноваційної лексики, утвореної на тлі політичної ситуації в Україні початку XXI століття. Дослідження й узагальнення інноваційних змін в українській мові, спричинених впливом політичних подій сучасного періоду, дало змогу визначити семантичні та функціональні особливості інноваційної лексики; з'ясувати роль екстралінгвальних чинників у формуванні неологізмів суспільно-політичного змісту; виявити причини набування новою лексикою позитивних та негативних конотацій; простежити наслідки активного входження неологізмів у систему мови.

Виокремлені неологізми сучасного періоду $є$ маркерами епохи й перебувають на стадії адаптації. Під впливом суспільно-політичних чинників у мові формується експресивний ідеолексикон, комплекс посилено-виразних слів, які мають політичне звучання та здатні 
вербалізувати соціальну оцінку дійсності. Частина 3 них є сумнівними 3 погляду політичної етики. Це створює можливості для маніпулювання суспільною свідомістю, дезінформації громадськості.

Активний процес неологізації, поява значної кількості іншомовних лексем, зокрема англізмів, загрожує естетичній та культурологічній функціям мови, а отже, виникає потреба розв'язання проблеми збереження мовної ідентичності українського народу, посилення контролю за входженням неологізмів до лексикографічних та політологічних видань, їхнім усталенням у словниковому складі мови; 3'являється необхідність проведення ефективної просвітницької кампанії серед політичних діячів із метою набуття ними вмінь дотримуватися мовних норм, та культивування в суспільстві питань екології мови.

\section{ЛІТЕРАТУРА}

1. Бордюк Л. Екологія мови: український контекст. Україна проблема ідентичності: людина, економіка, суспільство : Конференція українських випускників програм наукового стажування у США, Львів, 18-21 вересня 2003 р. Львів, 2003. С. 35-40.

2. Ветухов А. Потебнианство. Родной язык в школе. 1923. Кн. 1. C. $110-116$.

3. Свграфова А. До питання про конотативні можливості власного імені (за матеріалами медіа). Сучасна украӥністика : наукові парадигми мови, історії, філософії : матеріали IV Міжнародної наукової конференції : збірник статей. Харків, 2014. С. 92-97.

4. Єрмоленко С. Мова і українознавчий світогляд : монографія. Київ : НДІУ, 2007. 444 с.

5. Іваноў Уладзіслаў. Як мова рэагуе на расейска-ўкраінскую вайну (паліталягічныя і сацыялінгвістычныя заўвагі). The Ideology and Politics Journal. 2018. № 3 (11). C. 26-51.

6. Кирилюк О. Суспільно-політичні неологізми як віддзеркалення мовної картини воєнного протистояння. Наукові записки Національного університету «Києво-Могилянська академія». Серія "Мовознавство». 2018. T. 1. C. $58-62$.

7. Кондратенко Н. Неологізми в сучасному українському політичному дискурсі: семантико-словотвірний аспект. Наукові пращяі Кам'янещь-Подільського нащіонального університету ім. Івана Огієнка. Серія «Філологічні науки». 2014. Вип. 37. С. 151-156.

8. Коробка Г. Гумористичний інтрадискурс мовної картини світу окупованого Криму. Вісник Київського начіонального лінгвістичного університету. Серія «Філологія». 2018. Т. 21. № 1. С. 69-80. 
9. Косович О. До питання про суть неологізму в сучасній лінгвістиці. Записки з романо-германської філології. 2012. Вип. 2. C. 71-79.

10. Новітня політична лексика (неологізми, оказіоналізми та інші новотвори) / за заг. ред. Н. Хоми. Львів : Новий Світ - 2000, 2015. 492 с.

11. Потебня А. Слово и миф. Москва : Правда, 1989. 624 с.

12. Семенюк О. Особливості сучасної комунікації як фактори впливу на процеси функціонування і засвоєння неологізмів. Наукові записки. Серія «Філологічні науки». Кіровоград, 2016. Вип. 145. С. 3-6.

13. Степаненко М. Політичне сьогодення української мови: актуальний перифрастикон. Харків, 2017. 616 с.

14. Стишов О. Динаміка лексичного складу сучасної української мови. Лексикологія. Лексикографія. Біла Церква : Авторитет, 2019. 198 с.

15. Тараненко О. Неологізм. Украӥнська мова : енциклопедія. Київ : Укр. енциклопедія ім. М. Бажана, 2004. С. 408-409.

\section{Information about the authors:}

Cheremska O. S.,

Ph. D., Professor,

Head of the Department of Ukrainian Studies and Language Training of Foreign Citizens Simon Kuznets Kharkiv National University of Economics 9-A, Nauky avenue, Kharkiv, 61166, Ukraine

Sukhenko V. H., Ph. D., Associate Professor, Associate Professor at the Department of Ukrainian Studies and Language Training of Foreign Citizens Simon Kuznets Kharkiv National University of Economics 9-A, Nauky avenue, Kharkiv, 61166, Ukraine 